Pak. j. sci. ind. res. Ser. B: biol. sci. 201356 (2) 98-104

\title{
Quantification and Detoxification of Aflatoxin in Food Items
}

\author{
Alim-un-Nisa ${ }^{a} *$, Naseem Zahra ${ }^{b}$, Sajila Hina ${ }^{a}$, Rizwan Hayat ${ }^{c}$ and Nusrat Ejaz ${ }^{a}$ \\ ${ }^{a}$ Food and Biotechnology Research Centre, PCSIR Laboratories Complex, Lahore-54600, Pakistan \\ ${ }^{b}$ Pakistan Institute of Technology for Minerals \& Advanced Engineering Materials (PITMAEM), \\ PCSIR Laboratories Complex, Ferozepur Road, Lahore-54600, Pakistan \\ 'Institute of Molecular Biology and Biotechnology, The University of Lahore, Lahore, Pakistan
}

(received August 1, 2012; revised December 23, 2012; accepted January 24, 2013)

\begin{abstract}
The present study was conducted to quantify and detoxify the aflatoxins in food items. For this purpose, total 30 samples of food were collected. The samples were quantified using thin layer chromatography (TLC) for the presence of aflatoxin level in food items. Out of them aflatoxins were not found in 10 samples. Remaining 20 aflatoxins +ve samples were treated with various chemical solutions i.e. $0.1 \% \mathrm{HCl}$, $0.3 \% \mathrm{HCl}, 0.5 \% \mathrm{HCl}, 10 \%$ citric acid, $30 \%$ citric acid, $50 \%$ calcium hydroxide, 0.2 and $0.3 \% \mathrm{NaOCl}, 96 \%$ ethanol and $99 \%$ acetone for detoxification. The aflatoxins were reduced to $55.1 \%, 90.9 \%, 28.08 \%$ and $80.0 \%$ in Super Sella rice, Super Basmati rice, Brown rice and White rice, respectively. The aflatoxin level was reduced in maize grain, damaged wheat, peanut, figs and dates upto $31.3 \%, 64.3 \%, 63.6 \%, 42.7 \%$ and $19.8 \%$, respectively. Aflatoxins were detoxified in cereals Dal Chana, Dal Mash, Dal Masoor), turmeric (Haldi) and Nigela seeds (Kalwangi) upto 70.5\%, 83.0\%, 46.2\%, 82.09\% and 36.9\%, respectively. Reduction of aflatoxins was carried out $39.7 \%, 7.1 \% 39.5 \% 82.0 \%$ and $62.0 \%$ in red chilli, makhana, corn flakes, desert (Kheer Mix) and pistachio. The significant results $(\mathrm{p}=0.042)$ of detoxification of aflatoxins in food items were obtained from present study.
\end{abstract}

Keywords: pepsin extraction, enzyme activity, stomach mucosa, buffalo

\section{Introduction}

Aflatoxins are toxic and carcinogenic metabolites produced by species of Aspergillus, especially Aspergillus flavus and Aspergillus parasiticus. The toxic effects include acute hepatitis, immune-suppression. In humans, the risks associated with aflatoxin consumption are well documented and the International Agency for Research on Cancer (IARC) has designated aflatoxin as a human liver carcinogen. Because of these toxic effects, the Food and Drug Administration regulates the aflatoxin concentration in food with aflatoxin. Commodities or food with aflatoxin exceeding $20 \mathrm{ppb}$ $(\mu \mathrm{g} / \mathrm{kg})$ cannot move in trade (Wogan, 1999). Very little was known about mould metabolites prior to 1961. In that year some alarming reports of a mysterious disease of Turkey poults came from South East of England, tentatively named as Turkey $\mathrm{X}$ disease. In 500 such outbreaks about $1,00,000$ poults, mostly between three to six weeks of ages, died. Similarly 5000 partridges and pheasants from one farm and 14000 ducklings from another farm died (Asplin and Carnaghan, 1961). Reports from other places also accumulated on outbreak of acute

*Author for correspondence; E-mail: nisaalim64@yahoo.com poisoning of farm animals such as pigs (Loosmore and Harding, 1961) and calves (Loosmore and Markson, 1961). Bioassay test on duckling also helped in furthering and establishing the toxic factor (Sargeant et al., 1961). Aflatoxins producing ability is confined to $A$. flavus and $A$. parasiticus. Strains of these two species are common and wide-spread and have been isolated from a number of different host materials. Colonies of $A$. flavus are green-yellow to yellow-green and that of $A$. parasiticus are dark green. The toxin is produced by mycelium and secreted into the medium or substrate, spores contain very little aflatoxin. Different strains of A. flavus produce varying amount of aflatoxin and same strains also produce varying amount of aflatoxins. Aflatoxin production is a genetical process depending on specific nutrient and environmental factors (Patterson, 1973). Investigation carried out by various researchers at Tropical Development and Research Institute, London indicated that $A$. flavus is found in the soil and air throughout the world. Both A. flavus and A. parasiticus are more prevalent in warmer climate and these moulds can be isolated from stores, dried stuff and tropical soil (Christensen, 1957). Aflatoxins naturally occur in rice (including brown, white, black, red and basmati) of 
different countries, including United State, Canada, Pakistan, India and Thailand (Bansal et al., 2011). Aflatoxins $\left(\mathrm{AFB}_{1}, \mathrm{AFB}_{2}, \mathrm{AFG}_{1}\right.$ and $\left.\mathrm{AFG}_{2}\right)$ also occur in freshly harvested corn grains in different regions of Brazil (Liliana et al., 2009). The presence of aflatoxins in red chillis may be a great threat to the health of populations. Total 183 samples of red chilli were screened out for aflatoxin determination. 48 samples were positive for Aflatoxins $\mathrm{B}_{1}$ with the range from 1.2 $\mathrm{ppb}$ to $968.3 \mathrm{ppb}$. Aflatoxin $\mathrm{B}_{2}$ was detected only in 3 samples with the range of $0.3 \mathrm{ppb}-159.8 \mathrm{ppb}$. Aflatoxin $\mathrm{G}_{1}$ and $\mathrm{G}_{2}$ were absent in all chilli samples (Nisa et al., 2012). Chronic poisoning of aflatoxin results in cancer (hepatocellular carcinoma) because liver is the target organ of aflatoxins. Acute intoxication of aflatoxins in human body is also lethal (Milita et al., 2010). Many countries regulate aflatoxin levels in their foods. USA and EU (Europe Union) permit level lower than $20 \mathrm{ppb}$ and Korea and Japan 10 ppb (Chiavaro et al., 2001). Due to its importance different food items were selected for this study and different chemicals were used for detoxification of aflatoxins in these food samples.

\section{Materials and Methods}

This study was conducted in Food and Biotechnology Research Centre of PCSIR Laboratories Lahore. The food samples were prepared for aflatoxin analysis (Begum et al., 1985). Aflatoxins were detected by Romers' method (Romer, 1975). Estimation of aflatoxins in toxic extracts was made by comparison with standard technique (AOAC, 2005). In this study, TLC technique was used for the determination of Aflatoxin in all samples.

Nature of samples. Samples of food such as Corn, Wheat, Wheat Flour, White Rice, Brown Rice, Super Basmati, Super Kernal Rice, Red Chilli, Pistachio, Cornflakes, Figs, Haldi, Garam Masala, Peanut, Kalwangi, Makhana and Dates were selected for the present study.

Sample collection. During research work food samples were collected from local market of the city and brought to the Laboratory for quantitative determination and detoxification.

Sampling. Since the aflatoxins are not uniformly distributed in commodities, grains were likely to have pockets of high aflatoxin concentration, firstly due to highly heterogeneous distribution of aflatoxins and secondly due to marketing in lumps of various sizes. To obtain most representative sample, a suitable sampling plan was adopted. These commodities were found stacked in jute bags and stored in house type godown. In order to obtain a more representative portion of these samples, $500 \mathrm{~g}$ were collected through a sample probe directly in plastic bags piercing jute bags diagonally from 2 to 3 places. They were passed through sample divider and reduced to approximately $200 \mathrm{~g}$ for the purpose of analysis and thus a greater homogeneity of contaminated portion was achieved. Each sample was then thoroughly mixed, ground and made into fine powder for experimental analysis.

Extraction. Extraction procedures and analytical methods vary from one commodity to another because of diverse chemical composition, preventing the development of any one method which could be applied uniformly to all products. However, extraction with chloroform is most suitable method for aflatoxins $\left(B_{1}\right.$, $\mathrm{B}_{2}, \mathrm{G}_{1}, \mathrm{G}_{2}, \mathrm{M}_{1}$ and $\mathrm{M}_{2}$ ).

Then test portion was taken from mixture. $50 \mathrm{~g}$ of ground sample was kept into $500 \mathrm{~mL}$ conical flask and $25 \mathrm{~mL}$ water and $150 \mathrm{~mL}$ chloroform was added into flask. Conical flask was shaken on wrist action shaker for $30 \mathrm{~min}$ and sample was filtered through filter paper. $50 \mathrm{~mL}$ chloroform was taken into beaker and put on steam bath for evaporation.

Chromatographic tank. The dilutions for spotting were got in micro liter. The $25 \mu \mathrm{L}$ spot of test solution was applied on thin layer chromatography plate with micro syringe. Spot of 5 or $10 \mu \mathrm{L}$ of aflatoxins $\left(\mathrm{B}_{1}, \mathrm{~B}_{2}\right.$, $G_{1}, G_{2}, M_{1}$ and $M_{2}$ ) standard was spotted on same plate as an internal standard. The plate was developed with anhydrous ether in thin layer chromatographic tank upto half then removed and dried. Then plate was redeveloped in the same direction in thin layer chromatographic tank with acetone-chloroform (1:9). Plate was removed and test solution spot was observed for presence or absence of aflatoxins under UV light. If preliminary plate would show that new concentration of test solution required then new concentration were prepared for spotting. Different 1 to $25 \mu \mathrm{L}$ spots of test solution $(3.5,10.5,24.9 \mu \mathrm{L})$ were spotted on new thin layer chromatographic plate and on the same plate 1 to 25 $\mu \mathrm{L}$ aflatoxins standard was spotted (Braicu et al., 2008).

Detection and Estimation. Fluorescing intensities of sample spots were compared with those of standard aflatoxin spots. In case, fluorescing spot of sample lied between the standard spots, the average value of two standard spots was taken into consideration. 
Confirmation. Another very important step in the aflatoxins analysis was the fluorescing sample spots. This was carried out by spraying, evenly the thin layer chromatographic plate with aqueous sulphuric acid $(50 / 50 \mathrm{v} / \mathrm{v})$. After the spraying, thin layer chromatographic plate was allowed to dry and then viewed under UV light (365 nm).

Calculation. Concentration of aflatoxins $(\mu \mathrm{g} / \mathrm{kg})$ present in sample was calculated as follows.

Aflatoxins $(\mu \mathrm{g} / \mathrm{kg})=\frac{\mathrm{S} \times \mathrm{Y} \times \mathrm{V}}{\mathrm{Z} \times \mathrm{W}}$

Where:

$\mathrm{S}=$ volume in $\mu \mathrm{L}$ of aflatoxins standard of equivalent intensity to $\mathrm{Z}$ ( $\mu \mathrm{L}$ of sample)

$\mathrm{Y}=$ concentration of aflatoxins standard in $\mu \mathrm{g} / \mathrm{mL}$ $\mathrm{V}=$ volume in $\mu \mathrm{L}$ of solvents required to dilute final extract

$\mathrm{Z}=$ volume in $\mu \mathrm{L}$ of sample extract required to give fluorescence intensity comparable to that of $\mathrm{S}=\mu \mathrm{L}$ of aflatoxins standard

$\mathrm{W}=$ weight in $\mathrm{g}$ of original sample contained in final extract

Treatment for detoxification. Fifty grams of grinded samples in which aflatoxins had been detected were kept in separate $500 \mathrm{~mL}$ conical flasks. Chemical solutions of $0.1 \% \mathrm{HCl}, 0.3 \% \mathrm{HCl}, 0.5 \% \mathrm{HCl}, 10 \%$ citric acid, $30 \%$ citric acid, $05 \%$ calcium hydroxide, 0.2 and $0.3 \% \mathrm{NaOCl}$, $96 \%$ ethanol and $99 \%$ acetone were added into different flasks (Table 1). Conical flasks were shaken on wrist action shaker for $2 \mathrm{~h}$ and sample was filtered through filter paper and dried for two days.

Quantification after detoxification. Quantification of detoxified sample for aflatoxins was carried out by same method such as chloroform extraction, detection by thin layer chromatography, estimation through UV light and calculation by formula.

Statistical analysis. The statistical significance of the data was analyzed $(\mathrm{p}=0.042)$ using pair t-test (Steel et al., 1997).

\section{Results and Discussion}

Aflatoxins were detoxified by the treatment of different chemical solutions. For this purpose, total 30 samples were collected. These 30 samples were quantified using thin layer chromatography (TLC) for the presence of aflatoxins level in food items (Table 2). The aflatoxins were not found in 10 samples of food product, remaining
20 samples of food in which aflatoxins had been found were treated with chemical solutions.

Chemical solutions $0.1 \%, 0.3 \%$ and $0.5 \%$ of hydrochloric acid reduced aflatoxins to $39.7 \%, 55.1 \%, 90.9 \%, 39.5 \%$, $62.0 \%$ and $82.0 \%$ in food items (Table 4 ) which are in line with work of Aly and Hathout (2011) who reduced aflatoxins $27.6 \%, 42.5 \%$ and $90 \%$ in food with concentrations of hydrochloric acid at different hours. Aflatoxins also reduced to $49.3 \%, 86.5 \%$ and $71.39 \%$ with concentration of $0.1 \%, 0.3 \%$ and $0.5 \%$ of hydrochloric acid which is same work as Aly and Hathout (2011) who did reduction of food items.

Aflatoxins reduced to $31.3 \%, 64.3 \%, 19.8 \%, 28.08 \%$, $70.5 \%$ and $83.05 \%$ with treatment of $10 \%$ citric acid, $30 \%$ citric acid, $1 \%$ sodium bisulphate, $2 \%$ sodium bisulphate, $0.2 \%$ sodium hypochlorite and $0.3 \%$ sodium hypochlorite in food items and Aflatoxins reduced to $63.0 \%, 70.0 \%$, $69.16 \%, 53.9 \%, 10.0 \%$ and $35.05 \%$ with treatment of $10 \%$ citric acid, $30 \%$ citric acid, $1 \%$ sodium bisulphate, $2 \%$ sodium bisulphate $0.2 \%$ sodium hypochlorite and $0.3 \%$ sodium Hypochlorite in food items which are in line with work of Mukendi et al. (1991). They had detoxified

Table 1. Solutions for detoxification of Aflatoxins in food items

\begin{tabular}{ll}
\hline \hline Food product & $\begin{array}{l}\text { Chemical solution } \\
\text { for detoxification }\end{array}$ \\
\hline Red chilli & $0.1 \% \mathrm{HCl}$ \\
& $0.3 \% \mathrm{HCl}$ \\
Red chilli & $5 \% \mathrm{NaOH}$ \\
Super Sella rice & $0.3 \% \mathrm{HCl}$ \\
Super Basmati rice & $0.5 \% \mathrm{HCl}$ \\
White rice & $5 \% \mathrm{Ca}(\mathrm{OH})_{2}$ \\
Maize grain & $10 \% \mathrm{Citric}$ acid \\
Wheat damage & $30 \% \mathrm{Citric}$ acid \\
Peanut & $99 \% \mathrm{Acetone}$ \\
Figs & $96 \% \mathrm{Ethanol}$ \\
Dates & $1 \% \mathrm{Sodium}$ bisulphate \\
Brown rice & $2 \% \mathrm{Sodium}$ bisulphate \\
Makhana & $5 \% \mathrm{KOH}$ \\
Dal chana & $0.2 \% \mathrm{NaOCl}$ \\
Dal mash & $0.3 \% \mathrm{NaOCl}$ \\
Corn flakes & $0.1 \% \mathrm{HCl}$ \\
Kheer mix & $0.3 \% \mathrm{HCl}$ \\
Pistachio & $0.5 \% \mathrm{HCl}$ \\
Haldi & $5 \% \mathrm{Ca}(\mathrm{OH})_{2}$ \\
Kalwangi & $10 \% \mathrm{Citric}$ acid \\
Dal masoor & $99 \% \mathrm{Acetone}$ \\
\hline \hline
\end{tabular}


Table 2. Detection and estimation of Aflatoxins in food products

\begin{tabular}{|c|c|c|c|c|c|c|c|c|}
\hline $\begin{array}{l}\text { Sample } \\
\text { No. }\end{array}$ & $\begin{array}{l}\text { Food } \\
\text { product }\end{array}$ & Aflatoxin & S & $\mathrm{Y}$ & $\mathrm{V}$ & Z & W & ppb \\
\hline 1. & Red chilli & $\mathrm{B}_{1}$ & 0.5 & 2.02 & $\begin{array}{l}0.5 \\
(1000)\end{array}$ & 4.7 & 15.04 & 7.14 \\
\hline 2. & Red chilli & $\mathrm{B}_{1}$ & 2 & 2.02 & $\begin{array}{l}0.51 \\
(1000)\end{array}$ & 4.9 & 16.72 & 25.15 \\
\hline 3. & $\begin{array}{l}\text { Super Sella } \\
\text { rice }\end{array}$ & $\mathrm{B}_{1}$ & 2 & 2.02 & $\begin{array}{l}0.51 \\
(1000)\end{array}$ & 2.9 & 16.78 & 42. \\
\hline 4. & $\begin{array}{l}\text { Super Basmati } \\
\text { rice }\end{array}$ & $\mathrm{B}_{1}$ & 5 & 2.02 & $\begin{array}{l}0.99 \\
(1000)\end{array}$ & 0.9 & 16.92 & 656.9 \\
\hline 5. & Dal mash & Absent & & & 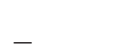 & & & - \\
\hline 6. & White rice & $\mathrm{B}_{1}$ & 8.5 & 2.02 & $\begin{array}{l}0.51 \\
(1000)\end{array}$ & 24.9 & 16.70 & 125.53 \\
\hline 7. & Pistachio & Absent & - & - & - & - & - & - \\
\hline 8. & Haldi & Absent & - & - & - & - & - & - \\
\hline 9. & Maize grain & $\mathrm{G}_{1}$ & 0.5 & 2.03 & $\begin{array}{l}0.51 \\
(1000)\end{array}$ & 0.9 & 16.65 & 34.48 \\
\hline 10. & Wheat damage & $\mathrm{B}_{1}$ & 0.9 & 2.02 & 1470 & 0.9 & 16.67 & 174.32 \\
\hline 11. & Peanut & $\mathrm{B}_{1}$ & 8.5 & 2.02 & $\begin{array}{l}0.51 \\
(1000)\end{array}$ & 4.9 & 16.70 & 21.08 \\
\hline 12. & Figs & $\mathrm{B}_{1}$ & 1.0 & 2.02 & $\begin{array}{l}0.50 \\
(1000)\end{array}$ & 1.0 & 16.77 & 14.9 \\
\hline 13. & Dates & $\mathrm{B}_{1}$ & 0.5 & 2.02 & 1980 & 3.9 & 16.68 & 30.76 \\
\hline 14. & Brown rice & $\mathrm{B}_{1}$ & 2 & 2.02 & $\begin{array}{l}0.51 \\
(1000)\end{array}$ & 1.0 & 16.76 & 123.58 \\
\hline 15. & Makhana & $\mathrm{B}_{1}$ & 0.5 & 2.02 & $\begin{array}{l}0.51 \\
(1000)\end{array}$ & 14.9 & 16.73 & 2.09 \\
\hline 16. & Dal chana & $\mathrm{B}_{1}$ & 0.5 & 2.02 & $\begin{array}{l}0.99 \\
(1000)\end{array}$ & 14.9 & 16.72 & 8.02 \\
\hline $\begin{array}{l}17 . \\
18 .\end{array}$ & $\begin{array}{l}\text { Figs } \\
\text { Peanut }\end{array}$ & $\begin{array}{l}\text { Absent } \\
\text { Absent }\end{array}$ & - & - & - & - & - & - \\
\hline 19. & Dal mash & $\mathrm{B}_{1}$ & $\overline{0} .5$ & $\overline{2} .02$ & $\begin{array}{l}\overline{0} .5 \\
(1000)\end{array}$ & $\overline{4} .7$ & $\overline{15} .04$ & $\overline{7} .14$ \\
\hline 20. & Corn flakes & $\mathrm{B}_{1}$ & 1.0 & 2.02 & $\begin{array}{l}1 \\
(1000)\end{array}$ & 9.5 & 16.27 & 13.0 \\
\hline 21. & White rice & Absent & - & & - & - & & \\
\hline 22. & Kheer mix & $\mathrm{B}_{1}$ & 0.9 & 2.02 & $\begin{array}{l}0.51 \\
(1000)\end{array}$ & 4.9 & 16.70 & 11.32 \\
\hline 23. & Pistachio & $\mathrm{B}_{1}$ & 1.0 & 2.02 & $\begin{array}{l}3.0 \\
(1000)\end{array}$ & 2.9 & 16.51 & 167.17 \\
\hline 24. & Haldi & $\mathrm{B}_{1}$ & 1 & 2.02 & 1980 & 2.9 & 16.68 & 82.68 \\
\hline $\begin{array}{l}25 . \\
26\end{array}$ & Peanut & Absent & - & - & - & - & - & - \\
\hline 26. & Brown rice & Absent & - & - & - & - & & - \\
\hline 27. & Kalwangi & $\mathrm{B}_{1}$ & 4.0 & 2.02 & $\begin{array}{l}0.51 \\
(1000)\end{array}$ & 5.0 & 16.72 & 49.2 \\
\hline $\begin{array}{l}28 . \\
29 .\end{array}$ & $\begin{array}{l}\text { Super Sella rice } \\
\text { Super Basmati rice }\end{array}$ & $\begin{array}{l}\text { Absent } \\
\text { Absent }\end{array}$ & - & - & - & - & - & - \\
\hline 30. & Dal masoor & $\mathrm{B}_{1}$ & 2.0 & 2.02 & $\begin{array}{l}0.91 \\
(1000)\end{array}$ & 2.9 & 16.67 & 76.05 \\
\hline
\end{tabular}


aflatoxins by comparing chemicals citric acid, sodium bisulphate, sodium hypochlorite (Table 3 and Table 4).

The present study showed significant detoxification in aflatoxins $(p=0.042)$ of food items when pair T-test was applied to quantified aflatoxins of food items before and after detoxification. It means that aflatoxins had been reduced statistically when aflatoxins were compared before and after detoxification.

Present study also showed that thin layer chromatography is a reliable method for detection and quantification of aflatoxins in food items before and after detoxification. (Okwu et al., 2010, Olufunmilayo and Oyefolu, 2010).

Table 3. Detection and estimation in Aflatoxins in food products after detoxification

\begin{tabular}{|c|c|c|c|c|c|c|c|c|}
\hline $\begin{array}{l}\text { Sample } \\
\text { No. }\end{array}$ & $\begin{array}{l}\text { Food } \\
\text { product }\end{array}$ & Aflatoxin & $\mathrm{S}$ & $\mathrm{Y}$ & V & Z & W & $\mathrm{ppb}$ \\
\hline 1. & Red chilli & $\mathrm{B}_{1}$ & 0.9 & 2.02 & $\begin{array}{l}0.99 \\
(1000)\end{array}$ & 24.9 & 16.67 & 4.3 \\
\hline 2. & Red chilli & $\mathrm{B}_{1}$ & 0.9 & 2.02 & $\begin{array}{l}0.51 \\
(1000)\end{array}$ & 4.9 & 16.71 & 11.34 \\
\hline 3. & $\begin{array}{l}\text { Super Sella } \\
\text { rice }\end{array}$ & $\mathrm{B}_{1}$ & 0.5 & 2.02 & $\begin{array}{l}0.91 \\
(1000)\end{array}$ & 2.9 & 16.67 & 19.01 \\
\hline 4. & $\begin{array}{l}\text { Super Basmati } \\
\text { rice }\end{array}$ & $\mathrm{B}_{1}$ & 2.5 & 2.02 & $\begin{array}{l}1975 \\
(1000)\end{array}$ & 2.0 & 16.70 & 59.68 \\
\hline 6. & White rice & $\mathrm{B}_{1}$ & 2.0 & 2.02 & 0.51 & 4.9 & 16.72 & 25.51 \\
\hline 9. & Maize grain & $\mathrm{G}_{1}$ & 9.5 & 2.03 & $\begin{array}{l}0.51 \\
(1000)\end{array}$ & 24.9 & 16.71 & 23.67 \\
\hline 10. & Wheat damage & $\mathrm{B}_{1}$ & 1.0 & 2.02 & $\begin{array}{l}0.515 \\
(1000)\end{array}$ & 1.0 & 16.69 & 62.31 \\
\hline 11. & Peanut & $\mathrm{B}_{1}$ & 1.5 & 2.02 & $\begin{array}{l}0.99 \\
(1000)\end{array}$ & 24.9 & 16.77 & 7.2 \\
\hline 12. & Figs & $\mathrm{B}_{2}$ & 0.5 & 0.5 & $\begin{array}{l}0.48 \\
(1000)\end{array}$ & 0.9 & 16.56 & 8.54 \\
\hline 13. & Dates & $\mathrm{B}_{1}$ & 2 & 2.02 & $\begin{array}{l}0.50 \\
(1000)\end{array}$ & 4.9 & 16.72 & 24.66 \\
\hline 14. & Brown rice & $\mathrm{B}_{1}$ & 8.5 & 2.02 & $\begin{array}{l}0.51 \\
(1000)\end{array}$ & 5.9 & 16.71 & 88.87 \\
\hline 15. & Makhana & $\mathrm{B}_{1}$ & 0.5 & 2.02 & $\begin{array}{l}0.51 \\
(1000)\end{array}$ & 5.9 & 16.72 & 1.94 \\
\hline 16. & Dal chana & $\mathrm{B}_{1}$ & 1 & 2.02 & 487 & 24.9 & 16.68 & 2.36 \\
\hline 19. & Dal mash & $\mathrm{B}_{1}$ & 0.5 & 2.02 & $\begin{array}{l}0.50 \\
(1000)\end{array}$ & 24.9 & 16.69 & 1.21 \\
\hline 20. & Corn flakes & $\mathrm{B}_{1}$ & 0.5 & 2.02 & $\begin{array}{l}0.51 \\
(1000)\end{array}$ & 3.9 & 16.69 & 7.9 \\
\hline 22. & Kheer mix & $\mathrm{B}_{1}$ & 0.9 & 2.02 & $\begin{array}{l}0.99 \\
(1000)\end{array}$ & 24.9 & 16.77 & 4.3 \\
\hline 23. & Pistachio & $\mathrm{B}_{1}$ & 0.5 & 2.02 & 1980 & 3.9 & 16.68 & 30.7 \\
\hline 24. & Haldi & $\mathrm{B}_{1}$ & 6.0 & 2.02 & $\begin{array}{l}0.51 \\
(1000)\end{array}$ & 24.9 & 16.69 & 14.8 \\
\hline 27. & Kalwangi & $\mathrm{B}_{1}$ & 7.5 & 2.02 & $\begin{array}{l}0.51 \\
(1000)\end{array}$ & 14.9 & 16.72 & 31.0 \\
\hline 30. & Dal masoor & $\mathrm{B}_{1}$ & 3.0 & 2.02 & $\begin{array}{l}0.50 \\
(1000)\end{array}$ & 4.7 & 15.90 & 40.9 \\
\hline
\end{tabular}


Table 4. Comparison of Aflatoxins estimation of food products before and after detoxification

\begin{tabular}{|c|c|c|c|c|c|c|}
\hline $\begin{array}{l}\text { Sample } \\
\text { No. }\end{array}$ & $\begin{array}{l}\text { Food } \\
\text { product }\end{array}$ & Aflatoxin & $\begin{array}{l}\text { Estimation } \\
\text { before } \\
\text { detoxification } \\
\text { (ppb) }\end{array}$ & $\begin{array}{l}\text { Chemical } \\
\text { solution for } \\
\text { detoxification }\end{array}$ & $\begin{array}{l}\text { ppb } \\
\text { after } \\
\text { detoxification }\end{array}$ & $\begin{array}{l}\text { Reduction } \\
\text { in \%age }\end{array}$ \\
\hline 1. & Red chilli & $\mathrm{B}_{1}$ & 7.14 & $0.1 \% \mathrm{HCl}$ & 4.3 & 39.7 \\
\hline 2. & Red chilli & $\mathrm{B}_{1}$ & 25.15 & $5 \% \mathrm{NaOH}$ & 11.34 & 54.9 \\
\hline 3. & Super Sella rice & $\mathrm{B}_{1}$ & 42.34 & $0.3 \% \mathrm{HCl}$ & 19.01 & 55.1 \\
\hline 4. & Super Basmati rice & $\mathrm{B}_{1}$ & 656.9 & $0.5 \% \mathrm{HCl}$ & 59.68 & 90.9 \\
\hline 6. & White rice & $\mathrm{B}_{1}$ & 125.53 & $5 \% \mathrm{Ca}(\mathrm{OH})$ & 25.51 & 80.0 \\
\hline 9. & Maize grain & $\mathrm{G}_{1}$ & 34.48 & $10 \%$ Citric acid & 23.67 & 31.3 \\
\hline 10. & Wheat damage & $\mathrm{B}_{1}$ & 174.32 & $30 \%$ Citric acid & 62.31 & 64.3 \\
\hline 11. & Peanut & $\mathrm{B}_{1}$ & 21.08 & $99 \%$ Acetone & 7.2 & 63.67 \\
\hline 12. & Figs & $\mathrm{B}_{2}$ & 14.9 & $96 \%$ Ethanol & 8.54 & 42.7 \\
\hline 13. & Dates & $\mathrm{B}_{1}$ & 30.76 & $1 \%$ Sodium bisulphate & 24.66 & 19.8 \\
\hline 14. & Brown rice & $\mathrm{B}_{1}$ & 123.58 & $2 \%$ Sodium bisulphate & 88.87 & 28.08 \\
\hline 15. & Makhana & $\mathrm{B}_{1}$ & 2.09 & $5 \% \mathrm{KOH}$ & 1.94 & 7.1 \\
\hline 16. & Dal chana & $\mathrm{B}_{1}$ & 8.02 & $0.2 \% \mathrm{NaOCl}$ & 2.36 & 70.5 \\
\hline 19. & Dal mash & $\mathrm{B}_{1}$ & 7.14 & $0.3 \% \mathrm{NaOCl}$ & 1.21 & 83.05 \\
\hline 20. & Corn flakes & $\mathrm{B}_{1}$ & 13.0 & $0.1 \% \mathrm{HCl}$ & 7.9 & 39.5 \\
\hline 22. & Kheer mix & $\mathrm{B}_{1}$ & 11.32 & $0.3 \% \mathrm{HCl}$ & 4.3 & 62.0 \\
\hline 23. & Pistachio & $\mathrm{B}_{1}$ & 167.17 & $0.5 \% \mathrm{HCl}$ & 30.7 & 82.0 \\
\hline 24. & Haldi & $\mathrm{B}_{1}$ & 82.68 & $50 \% \mathrm{Ca}(\mathrm{OH})_{2}$ & 14.8 & 82.09 \\
\hline 27. & Kalwangi & $\mathrm{B}_{1}$ & 49.2 & $10 \%$ Citric acid & 31.0 & 36.9 \\
\hline 30. & Dal masoor & $\mathrm{B}_{1}$ & 76.05 & $99 \%$ Acetone & 40.9 & 46.2 \\
\hline
\end{tabular}

Ultra-violet (UV) light, a standard procedure was used to differentiate the toxin from non-toxin forms of $A$. spergillus species.

\section{Conclusion}

It was concluded that significant detoxification i.e. $90.9 \%$ was observed when $0.5 \% \mathrm{HCl}$ was used as detoxifying agent for aflatoxin $\mathrm{B}_{1}$ in Super Basmati rice. Similarly, $83.05 \%$ detoxification of Aflatoxin $\mathrm{B}_{1}$ was observed in Dal Mash, $82.09 \%$ in Haldi, $82 \%$ in Pistachio and $80 \%$ in White rice when $0.3 \% \mathrm{NaOCl}, 50 \% \mathrm{Ca}(\mathrm{OH})_{2}, 0.5 \%$ $\mathrm{HCl}$ and $5 \% \mathrm{Ca}(\mathrm{OH})_{2}$ were used, respectively.

\section{References}

Braicu, C.,Puia, C., Bodoki, E., Socaciu, C. 2008. Screening and quantification of aflatoxins and ochratoxin A in different cereals cultivated in Romania using thin layer chromatography. Journal of Food Quality, 31: 108-120.
Chiavaro, E., Dall., A.Sta, C., Galaverna, G., Biancardi, A., Gambarelli, E., Dossena, A., Marchelli, R. 2001. New reversed-phase liquid chromatographic method to detect aflatoxins in food and feed with cyclodextrins as fluorescence enhancers added to the eluent. Journal of Chromatography A, 937: 31-40.

Christensen, C.M. 1957. Deterioration of stored grains by fungi. The Botanical Review, 23: 108-134.

Liliana, O.R., Viviane, K.N., Raquel, B., Tatiana, A.R., Estela, K., Benedito, C. 2009. Mycoflora and cooccurrence of fumonisins and aflatoxins in freshly harvested corn in different regions of Brazil. International Journal of Molecular Sciences, 10: 5090-5103.

Loosmore, R.M., Harding, J.D.J. 1961. A toxic factor in Brazilian groundnut meal causing liver damage in pigs. Veterinary Record, 73: 1362-1364.

Loosmore, R.M., Markson, L.M. 1961. Poisioning of cattle by brazilian groundnut meal. Veterinary 
Record, 73: 813-814.

Milita, N.M. Mihaescu, G., Chifiriuc, C. 2010. Aflatoxins--health risk factors. Bacteriol Viruses Parazitol Epidemiol, 55: 19-24.

Mukendi, N., Rollmann, B., de Meester, C. 1991. Detoxification of aflatoxin $\mathrm{B} 1$ by different chemical methods and evaluation of the effectiveness of the treatments applied. Journal de Pharmacie de Belgique, 46: 182-188.

Nisa, A., Zahra, N., Firdous, S., Ejaz, N., Hina, S. 2012. Detection of Aflatoxins in various samples of red chilli. Pakistan Journal of Scientific and Industrial Research, Ser B: Biological Sciences, 55: 27-29.

Okwu, G.I., Achar, P.N., Sharma, S.K. 2010. Quantification of aflatoxin B1 in ready-to-use food thickeners in South-east geo-political zone in Nigeria. African Journal of Microbiology Research, 4: 1788-1793.

Olufunmilayo, G.O., Oyefolu, A.B. 2010. Natural occurrence of aflatoxin residues in fresh and sun- dried meat in Nigeria, The Pan African Medical Journal, 7: 14.

Patterson, D.S.P. 1973. Metabolism as a factor in determining the toxic action of aflatoxins in different animal species. Food and Cosmetics Toxicology, 11: 287-294.

Romer, T.R. 1975. Screening method for detection of aflatoxins in mixed feed and other agriculture commodities. Journal of the Association of Official Analytical Chemists, 59: 500-506.

Sargeant, K., Sheridan, A., Kelley, J.O., Carnaghan, R.B.A. 1961. Toxic products with certain samples of groundnuts. Nature, 192: 1096-1097.

Steel, R.D., Torrie, J.H., Dickey, D. 1997. Principles and Procedures of Statistic: A Biometrical Approach, $3^{\text {rd }}$ edition, McGraw Hills Book Co. Inc, New York, USA.

Wogan, G.N. 1999. Aflatoxin as a human carcinogen. Hepatology, 30: 573-575. 